\title{
Linseed (Linum usitatissimum) Oil Extraction Using Different Solvents
}

\section{Guilherme Sabadin \\ Piva', Thiago André \\ Weschenfelder', Elton \\ Franceschi², Rogério Luis \\ Cansian', Natalia Paroul' \\ and Clarice Steffens ${ }^{1 *}$}

'Department of Food Engineering, UR Erechim, Av. Sete de Setembro 1621, 99700-000, Erechim, RS, Brazil

${ }^{2}$ Colloidal System Research Center (NUESC), Research and Technology Institute (ITP), Tiradentes University (UNIT), 49032-490, Aracaju, SE, Brazil

Received: 24 April 2017 Accepted: 23 May 2018

\footnotetext{
${ }^{*}$ Corresponding author:

Phone: +555435209000;

Fax: +555435209090

E-mail: claristeffens@yahoo.com.br

ORCID IDs: 0000-0001-8881-7477 (Sabadin Piva), 0000-0002-1562-5471 (Weschenfelder), 0000-0002-2675-7250 (Franceschi), 0000-0002-1857-9036 (Cansian), 0000-0001-9809-7944 (Paroul), 0000-0003-4394-125X (Steffens)
}

\section{SUMMARY}

This work aims at characterizing linseed oil obtained using different extraction methods (hexane, subcritical propane and pressurized ethanol), and comparing the results with commercial linseed oil extracted by cold mechanical press method. An experimental design helped to evaluate temperature and pressure effects on the oil extraction using propane and ethanol. Gas chromatography assisted in evaluating the essential fatty acids. There were no significant differences among the $\omega-3,6$ and 9 fatty acids from linseed oil obtained using the different extraction methods. Only the acidity of linseed oil extracted by subcritical propane $(0.956 \%)$ showed significant differences among the physicochemical parameters. Extraction using organic solvent (Soxhlet) gave a $36.12 \%$ yield. Extraction using subcritical propane at $10^{7} \mathrm{~Pa}$ and $40^{\circ} \mathrm{C}$ for $1.5 \mathrm{~h}$ gave a better yield (28.39\%) than pressurized ethanol $(8.05 \%)$ under similar conditions. Linseed oil extraction using subcritical propane was economically viable, resulting in a $124.58 \mathrm{US} \$ / \mathrm{L}$ product cost. The results present subcritical propane extraction as a promising alternative for obtaining linseed oil at mild temperature and pressure conditions, without losing quality and quantity of fatty acids such as $\omega-3,6$ and 9 .

Key words: linseed oil, fatty acids, extraction yield, extraction methods, oil quality

\section{INTRODUCTION}

Linseed (Linum usitatissimum) oil contains $40-50 \%$ a-linolenic ( $\omega-3)$ acid, which is rich in phytosterols and tocopherols. These bioactive components can improve the human immune system, prevent inflammation, reduce bad cholesterol absorption and help cardiovascular disease prevention $(1,2)$.

Vegetable oil industrial production uses mechanical press extraction. This method allows the utilization of residual cake, with low initial operation costs, and eliminates contaminants. However, it is not an efficient extraction process, extracting less than $70 \%$ oil content from the seed (3). Extraction with organic solvents (hexane, ethanol, heptane and isobutene) in industrial plants yields around $99 \%$ oil. However, this process shows a series of disadvantages including time-consuming procedures, low selectivity, solvent contamination and degradation of key bioactive components (3). Pressurized liquid extraction (PLE) with solvents occurs at temperatures above boiling point, when pressure in the extraction system increases. Pressure reduces solvent surface tension, which improves penetration into the matrix pores, resulting in rupture and increase of mass transfer, thus improving extraction efficiency (4-7).

Subcritical fluid extraction (SFE) has some advantages when compared to an organic solvent ( $n$-hexane) extraction, such as its use at low temperatures, short extraction time, good selectivity, and residual solvent elimination (8). The subcritical propane allows high extraction rates in processes with vegetable oil, due to the high triglyceride solubility in this solvent. Furthermore, it may be used at low pressures, unlike supercritical carbon dioxide $\left(\mathrm{scCO}_{2}\right)$, which is a major advantage for the oil industry (9). Literature offers works related to the use of subcritical propane for pequi (10), sesame seed (11), sunflower (12) and linseed (2) oil extractions. 
Extractions at low pressures and temperatures are attractive from an economic standpoint, giving high yield in short extraction time, hence reducing costs (13). In the same work extraction of coriander seed oil using propane as a solvent, under supercritical and subcritical conditions, using $2 \cdot 10^{7}$ and $3 \cdot 10^{7} \mathrm{~Pa}$ at $35^{\circ} \mathrm{C}$ for $\mathrm{CO}_{2}$ and $5 \cdot 10^{6}, 8 \cdot 10^{6}$ and $10^{7} \mathrm{~Pa}$ at $25^{\circ} \mathrm{C}$ for propane indicated that propane solvation power was much higher than $\mathrm{CO}_{2}$ (13).

Pradhan et al. (3) and Khattab and Zeitoun (14), using supercritical $\mathrm{CO}_{2}$ as a solvent for linseed oil extraction, at 3.107 Pa and $50{ }^{\circ} \mathrm{C}$ for $3 \mathrm{~h}$ and $4 \cdot 10^{7} \mathrm{~Pa}$ and $50{ }^{\circ} \mathrm{C}$ for $2 \mathrm{~h}$ obtained 35.3 and $36.5 \%$ yield, respectively. Zanqui et al. (2) obtained the highest yield ( $28.8 \%$ ) of linseed oil extracted with subcritical propane at $60^{\circ} \mathrm{C}$ and $1.2 \cdot 10^{7} \mathrm{~Pa}$ for $5 \mathrm{~h}$.

Due to linseed oil potential, studies to maximize production and improve oil quality by increasing the content of fatty acids are vital. Thus, the aim of this work is to evaluate three different linseed oil extraction methods (SFE, PLE and Soxhlet), in terms of yield, essential fatty acid content and physicochemical quality, in comparison with commercial oil.

\section{MATERIALS AND METHODS}

\section{Samples}

Brown linseed (Linum usitatissimum) samples ( $5 \mathrm{~kg}$ ) were obtained from the 2014-2015 harvest. The commercial linseed samples came from a local market (Pazze Foods Company), cultivated in the Panambi municipality (28 17' $33^{\prime \prime}$ latitude and 53 $36^{\prime} 47^{\prime \prime}$ longitude), Rio Grande do Sul State, Brazil. Mechanically pressed brown linseed oil $(150 \mathrm{~mL})$ came from Pazze Foods Company (Panambi, RS, Brazil).

\section{Sample preparation}

The linseed samples were oven-dried (MA035/1; Marconi Equipamentos para Laboratórios Ltda., Piracicaba, SP, Brazil) at $50{ }^{\circ} \mathrm{C}$ for $48 \mathrm{~h}$, vacuum packed using a Selovac $200 \mathrm{~B}$ (Selovac, São Paulo, SP, Brazil) and stored in a freezer (Brastemp, São Paulo, SP, Brazil) at $-18^{\circ} \mathrm{C}$. In order to perform oil extractions, samples were crushed in a mixer Cuisinart Brasil (São Paulo, SP, Brazil), and sieved through 16 and 32 mesh sizes, using the fraction retained in the 32 mesh sieve after passing the 16 mesh one, obtaining particle sizes of 500 to $1000 \mu \mathrm{m}$.

\section{Extraction methods}

\section{Organic solvent}

The organic solvent extraction ( $n$-hexane, $95 \%$ purity, Cinética, Londrina, PR, Brazil) in a Soxhlet equipment (Fisher Scientific, Thermo Fisher Scientific, Pittsburgh, PA, USA) lasted $14 \mathrm{~h}$, at $60-80^{\circ} \mathrm{C}$ with approx. $20 \mathrm{~g}$ ground linseed powder. After extraction, the sample was concentrated in a rotary evaporator (Q344B; Quimis, São Paulo, SP, Brazil) under vacuum at $40^{\circ} \mathrm{C}$. All extractions were performed in triplicate.

\section{Subcritical propane}

The extraction occurred in the packed bed extractor using propane with $99.97 \%$ purity (White Martins Gases Industriales Ltda., Rio de Janeiro, RJ, Brazil) in a subcritical state. The extraction equipment consisted of a solvent reservoir, two thermostatic baths (521/3D; Nova Ética, Vargem Grande do Sul, SP, Brazil), one syringe pump (500D; Teledyne ISCO, Lincoln, NE, USA) and a $62.8-\mathrm{mL}$ jacketed extraction vessel. Evaluation conditions were: 20,40 and $60^{\circ} \mathrm{C}$ and $8 \cdot 10^{6}, 10^{7}$ and $1.2 \cdot 10^{7} \mathrm{~Pa}$. All extractions required a constant $2 \mathrm{~mL} / \mathrm{min}$ flow rate. Ground linseed powder (16 g) was placed into the extraction vessel (a heating jacket with a thermostatic bath, model SE 100AG; Servilab, Le Mans, France), supported by two 150 mesh wire disks at both ends. The solvent was pumped at a constant flow rate into the extraction chamber and kept in contact with the bed and samples until reaching the desired extraction pressure. Extraction lasted for $90 \mathrm{~min}$. After that, the solvent feed was interrupted and the valve located at the bottom of the chamber was opened, obtaining the extracted oil mass. The micrometric expansion valve was wrapped in the temperature controller (HW 1440; Coel, São Paulo, SP, Brazil) to keep at a constant $55^{\circ} \mathrm{C}$. Linseed oil yield (\%) was calculated using the following equation:

$$
Y(\text { linseed oil })=\frac{m(\text { seed powder })}{m(\text { extracted oil })} \cdot 100
$$

where $Y$ is the yield of linseed oil (in \%), $m$ (seed powder) is the seed powder mass and $m$ (extracted oil) is the mass of oil extracted at the process end. All extractions were performed in triplicate.

\section{Pressurized ethanol}

For pressurized liquid extraction (PLE) the measuring cylinder containing ethanol (99\% purity; Vetec, Rio de Janeiro, RJ, Brazil) was connected to the HPLC pump (Lab Alliance Series III, New York, NY, USA) with two thermostatic baths (521/3D; Nova Ética). Evaluation conditions were: 20,40 and $60^{\circ} \mathrm{C}$ and $8 \cdot 10^{6}, 10^{7}$ and $1.2 \cdot 10^{7} \mathrm{~Pa}$. All extractions required a constant $2 \mathrm{~mL} / \mathrm{min}$ flow rate, using $16 \mathrm{~g}$ sample in the extraction cell. During the extraction step, the sample was loaded into the cell and the solvent was added at an operational pressure, until reaching the operational temperature. When the pressure reached the desired value, pump pressure was interrupted, and the system was isolated by closing the valve that releases the liquid to the pump, keeping it pressurized for $15 \mathrm{~min}$. Then, the pump was once again engaged, the micrometric valve was opened starting the extraction. Extraction lasted 90 min, and samples containing oil and ethanol were placed in an oven coupled to a vacuum pump (Quimis) at $50^{\circ} \mathrm{C}$, for solvent evaporation. Yield was calculated using Eq. 1. All extractions were performed in triplicate.

\section{Experimental design}

A $2^{2}$ experimental design with 3 central points using pressure of $8 \cdot 10^{6}, 10^{7}$ and $1.2 \cdot 10^{7} \mathrm{~Pa}$ and temperature of 20,40 and $60{ }^{\circ} \mathrm{C}$ for $90 \mathrm{~min}$ evaluated the effects of temperature and 
pressure on the extraction yield using subcritical propane and pressurized ethanol.

\section{Physicochemical analysis of linseed oil}

Acidity, refraction index, and density of the oil obtained with both extraction methods and the commercial oil were analyzed according to the methods described by the Adolfo Lutz Institute, São Paulo, Brazil (15). All physical and chemical analyses were performed in triplicate. Titratable acidity was determined by titrating a sample with $0.1 \mathrm{M}$ sodium hydroxide solution ( $\mathrm{NaOH}$; Synth, Diadema, SP, Brazil) and phenolphthalein as indicator. The refractive index was measured with an Abbé refractometer (Delta, São Paulo, SP, Brazil). Density was determined using a density bottle (4500 density meter; DMA, São Paulo, SP, Brazil) at $25^{\circ} \mathrm{C}$.

\section{Qualitative analysis of essential fatty acids}

The samples were esterified following the method set by the Adolfo Lutz Institute (15). A mass of $0.1 \mathrm{~g}$ oil was mixed with $0.2 \mathrm{~mL}(2 \mathrm{M})$ methanolic potassium hydroxide solution ( $\mathrm{KOH}$; Synth, and methanol; Merck, São Paulo, Brazil) and $2 \mathrm{~mL}$ $n$-hexane, and homogenized in a vortex mixer (Q220M; Quimis) for $30 \mathrm{~s}$. After that, $3 \mathrm{~mL}$ saturated sodium chloride solution ( $\mathrm{NaCl}$; Cinética, Londrina, PR, Brazil) were added and the supernatant was then removed.

\section{Chromatographic analysis}

Qualitative analysis of essential fatty acids followed the instructions of Khattab and Zeitoun (14), in a gas chromatograph (CG-2010 Plus model; Shimadzu do Brazil, Barueri, SP, Brazil) equipped with a polar column (Rtx-Wax Restek, 30 $\mathrm{m} \times 0.25 \mathrm{~mm}$ i.d., $0.25 \mu \mathrm{m}$ thickness) and a flame ionization detector, at the following temperatures: $80^{\circ} \mathrm{C}$ (5 min), 80-200 ${ }^{\circ} \mathrm{C}\left(20^{\circ} \mathrm{C} / \mathrm{min}\right), 200{ }^{\circ} \mathrm{C}(5 \mathrm{~min}), 200-230^{\circ} \mathrm{C}\left(5^{\circ} \mathrm{C} / \mathrm{min}\right), 230^{\circ} \mathrm{C}$ (10 min), injector temperature at $250^{\circ} \mathrm{C}$, detector at $275^{\circ} \mathrm{C}$, with a 50:1 split ratio. Nitrogen and synthetic air (White Martins Gases Industriales Ltda., $99.99 \%$ purity) were the carrier gases, with a $1.5 \mathrm{~mL} / \mathrm{min}$ flow rate. A diluted sample $(0.4 \mu \mathrm{L})$ in dichloromethane (1:10; Merck) was injected. The sample components were identified by comparing their mass spectra with the mass spectra and retention indices of linolenate methyl ester $(\omega-3)$, linoleatemethyl ester $(\omega-6)$ and oleatemethyl ester ( $\omega-9)$ standards (Sigma-Aldrich, Merck KGaA, St. Louis, MO, USA).

\section{Oil extraction cost analysis}

It is important to determine the relationship between the high extraction yield using propane and production costs. Based on the information generated by CONTAGRI software (16) the economic analysis generally depends on the total fixed and variable costs. In this way, the production costs included fixed and variable costs such as the raw material (seed), chemicals, reagents and gas (propane), equipment investment, and labour cost. Cost analysis of 16 working hours a day and 240 days a year of extraction unit operation took into consideration $1 \%$ for repair and maintenance, $10 \%$ for depreciation and $2 \%$ interest over a 10 -year period.

\section{Statistical analysis}

The data from the experimental design were subjected to analysis of variance (ANOVA), and their average values were compared using the Tukey's test at a $5 \%$ probability level for oil physicochemical analysis with Statistica v. 5.0 (17).

\section{RESULTS AND DISCUSSION}

\section{Extraction yield}

Linseed oil extraction using organic solvent ( $n$-hexane) gave a $36.1 \%$ yield in 14-hour extraction. Khattab and Zeitoun (14) obtained a $42.4 \%$ yield of linseed oil using the same extraction process; however, they did not mention the process extraction time. Table 1 shows the $2^{2}$ experimental design matrix for linseed oil yield using subcritical extraction.

Table 1. A $2^{2}$ experimental design matrix with real and coded values and linseed oil yield results using subcritical propane and pressurized ethanol

\begin{tabular}{cccccc} 
& \multicolumn{2}{c}{ Independent variable } & & \multicolumn{2}{c}{ Yield/\% } \\
\cline { 2 - 3 } \cline { 5 - 6 } Assay & Pressure/Pa & Temperature/ ${ }^{\circ} \mathrm{C}$ & & $\begin{array}{c}\text { Subcritical } \\
\text { propane }\end{array}$ & $\begin{array}{c}\text { Pressurized } \\
\text { ethanol }\end{array}$ \\
1 & $-1\left(8 \cdot 10^{6}\right)$ & $-1(20)$ & & 26.91 & 6.36 \\
2 & $-1\left(8 \cdot 10^{6}\right)$ & $1(60)$ & & 27.57 & 6.10 \\
3 & $1\left(1.2 \cdot 10^{7}\right)$ & $-1(20)$ & & 27.05 & 6.93 \\
4 & $1\left(1.2 \cdot 10^{7}\right)$ & $1(60)$ & & 28.31 & 7.23 \\
5 & $0\left(10^{7}\right)$ & $0(40)$ & & 28.39 & 7.99 \\
6 & $0\left(10^{7}\right)$ & $0(40)$ & & 28.12 & 7.89 \\
7 & $0\left(10^{7}\right)$ & $0(40)$ & & 28.29 & 8.05 \\
\hline
\end{tabular}

High extraction yields were obtained in the central point (assays 5-7) and in assay 4 (Table 1). These results were similar to the ones obtained by Zanqui et al. (2), who verified a $28.8 \%$ yield of linseed oil using subcritical extractions with propane at $1.2 \cdot 10^{7} \mathrm{~Pa}$ and $60^{\circ} \mathrm{C}$. Pradhan et al. (3) and Khattab and Zeitoun (14) also reported similar extraction yields using supercritical $\mathrm{CO}_{2}$ respectively at $3 \cdot 10^{7} \mathrm{~Pa}$ and 50 ${ }^{\circ} \mathrm{C}$ for $4 \mathrm{~h}(35.3 \%)$ and $4 \cdot 10^{7} \mathrm{~Pa}$ and $50{ }^{\circ} \mathrm{C}$ for $2 \mathrm{~h}(36.9 \%)$. Such high yields might be due to high operational pressure and extraction time conditions, and solubility of the different compounds in the extraction solvent. In addition, the amount of solvent for complete extraction $(12,18,19)$ was lower when using subcritical propane than when using supercritical $\mathrm{CO}_{2}$, making propane more attractive for industrial application.

Analysis of variance (ANOVA) served to see the effects of variables on the extraction yields of linseed oil using subcritical propane, observable in the Pareto chart (Fig. 1). Both temperature and pressure had significantly positive effects $(p<0.1)$ on the extraction yield during 90-min extraction (Fig. 1). 


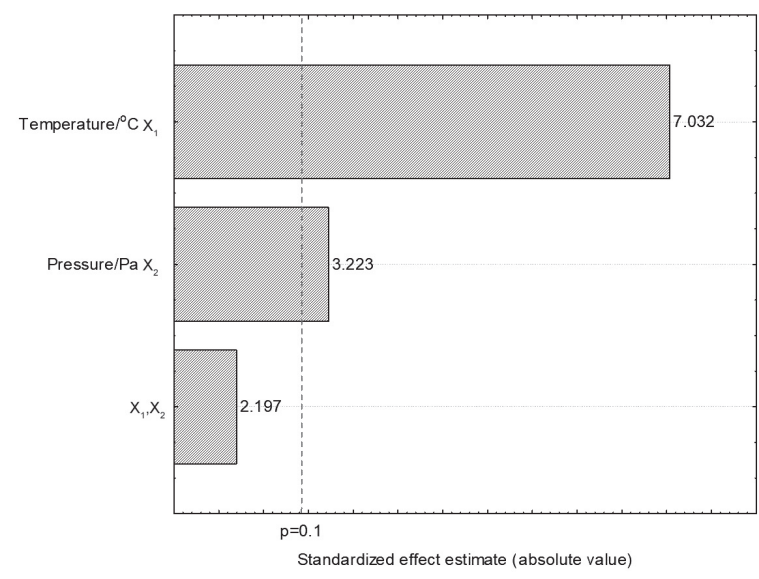

Fig. 1. Pareto chart for linseed oil extraction using subcritical propane at $90 \mathrm{~min}$

The following equation shows the first order-coded model for extraction yield as a function of temperature and pressure within the studied ranges:

$$
\text { Yield } / \%=27.8+0.48 t+0.22 p
$$

where $t$ is extraction temperature $\left({ }^{\circ} \mathrm{C}\right)$ and $p$ is extraction pressure $(\mathrm{Pa})$.

The independent variables showed a positive effect $(p<0.1)$, whereas the interactions were not significant. Analysis of variance (ANOVA) validated the model and the non-significant parameters were added to the lack of fit. The correlation coefficient was 0.9 , and the $\mathrm{F}$ calculated value was 0.25 times higher than the $\mathrm{F}$ tabulated one (Table 2), allowing the contour curve construction (Fig. 2).

Table 2. Analysis of variance for linseed oil extraction using subcritical propane

\begin{tabular}{lcccc} 
Source & $\begin{array}{c}\text { Sum of } \\
\text { squares }\end{array}$ & $\begin{array}{c}\text { Degree of } \\
\text { freedom }\end{array}$ & $\begin{array}{c}\text { Mean } \\
\text { square }\end{array}$ & F calculated \\
Recovery model & 1.205 & 1 & 1.20 & 5.23 \\
Residual & 1.153 & 5 & 0.23 & \\
Lack-of-fit & 1.115505 & 3 & & \\
Pure error & 0.037267 & 2 & & \\
Total & 2.357971 & 2 & & \\
\hline
\end{tabular}

Fig. 2 shows the increase of the extraction yield of linseed oil using subcritical propane with the increase of temperature and pressure.

Extraction using pressurized ethanol was performed under similar experimental conditions as the one using subcritical propane. The experimental design results (Table 1) showed that the highest yield (approx. $8 \%$ ) was obtained at the central point (assays 5, 6 and 7). According to Table 1, the extraction using pressurized ethanol showed a lower yield than those using subcritical propane and organic solvent ( $n$-hexane), which could be due to a short-chain alcohol that did not present any good solvency for triglycerides under the applied conditions. Besides that, this process requires, after extraction, an additional step for ethanol removal via evaporation, which is seen as a

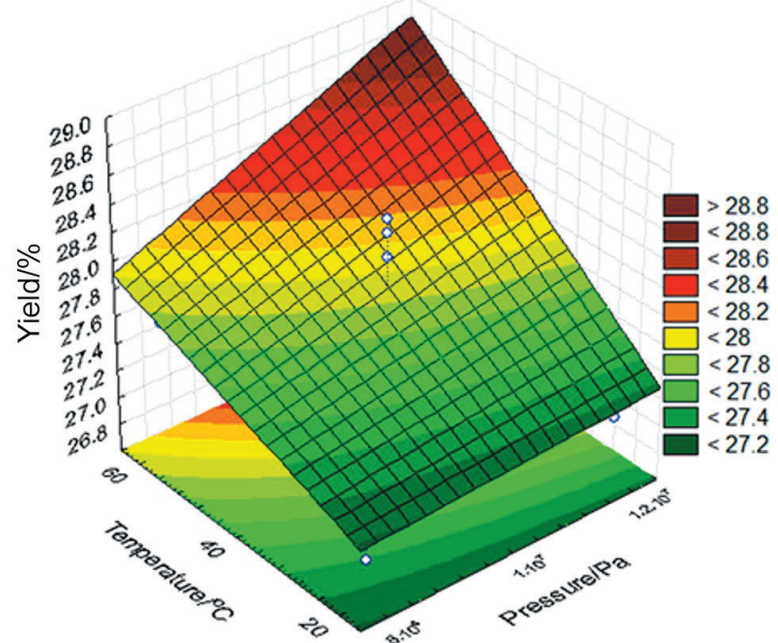

Fig. 2. Surface response for linseed oil extraction using subcritical propane

disadvantage, since it may cause loss or damage to certain oil components.

Jesus et al. (5) conducted a comparative study to evaluate palm oil extraction capacity with ethanol and propane under similar conditions $\left(10^{7} \mathrm{~Pa}\right.$ and $\left.20^{\circ} \mathrm{C}\right)$ yielding $53.3 \%$ with ethanol and $72.8 \%$ with propane. The authors observed that the solubility obtained with propane was higher than with ethanol, allowing total oil miscibility, and improving extraction yield.

Statistically treated results of linseed oil extraction with pressurized ethanol showed that both pressure and its interaction with temperature had a significantly positive effect $(p<0.1)$, observable in the Pareto chart (Fig. 3). The correlation coefficient was 0.92 and the $F$ calculated was 1.44 times lower than the $\mathrm{F}$ tabulated value, hence, neither validating the model nor allowing the contour curve construction. Based on that, in

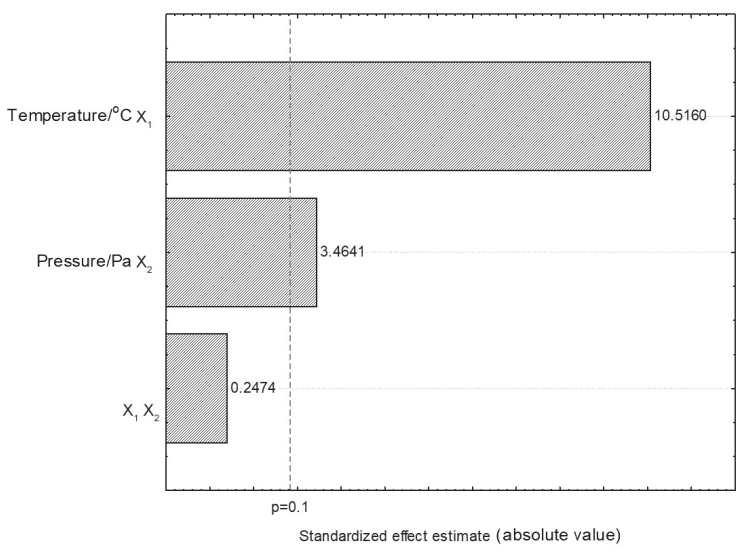

Fig. 3. Pareto chart for linseed oil extraction using pressurized ethanol

order to increase the yield, the extraction time was prolonged to $3 \mathrm{~h}$ under the experimental design central point conditions $\left(40^{\circ} \mathrm{C}\right.$ and $10^{7} \mathrm{~Pa}$ ). The improvement in the yield was $12.3 \%$; however, even lower than in the extraction with subcritical propane (28.4\%). 


\section{Fatty acids}

Table 3 shows the percentage of essential fatty acid esters obtained with different extraction methods from linseed oil, with methyl esters ranging from 49.8 to $55.0 \%$.

Using propane as a solvent, Zanqui et al. (2) reported the yields higher than $48.7 \% \omega-3$ and $12.3 \% \omega-6$ from linseed oil. Results closer to those reported in this study were found by Ivanov et al. (20), who obtained $53.7 \% \omega-3,16.17 \% \omega-6$ and 19.4 $\% \omega$-9 from linseed oil extracted using $\mathrm{CO}_{2}$, however, the used pressure ranged from 4.5 to $6.2 \cdot 10^{9} \mathrm{~Pa}$, which may be explained by the extraction processing conditions and seed origin.

The statistical analysis of extraction using pressurized ethanol did not show any significant differences among acid esters, whereas the extraction with subcritical propane resulted in significant differences in linolenate $(\omega-3)$ and linoleate $(\omega$ 6) concentration. Extraction yields demonstrated that the concentrations of $\omega-3,-6$ and -9 from linseed oil extracted using pressurized ethanol were similar to the ones found using subcritical propane (Table 3).

There were no statistical differences in the amounts of essential fatty acid esters obtained with the organic solvent and mechanical pressing, whose major component was linolenate (approx. $55 \%$ ), corresponding to the $\omega-3$ fatty acid, followed by oleate (19\%) (matching the $\omega-9$ fatty acid). Such results corroborated those found in the literature. Pradhan et al. (3) obtained $53.8 \% \omega-3$ and $15.6 \% \omega-6$ from linseed oil extracted using mechanical pressing and $50 \% \omega-3$ and $14.4 \% \omega-6$ in the oil extracted using organic solvent. Linseed oil extracted with $n$-hexane contained 56.28 and $15.6 \% \omega-3$ and $\omega-6$, respectively (14).

The area sum (\%) of fatty acid esters (linolenate ( $\omega-3)$, linoleate $(\omega-6)$ and oleate $(\omega-9))$ was around $86 \%$ (Table 3 ). The remaining $14 \%$ may be related to the amounts of both palmitic and stearic acids. Studies in the literature of fatty acid composition from linseed oil showed 45.1-73.4 \% linolenic, 11.9-20\% linoleic, $17.1-24.3 \%$ oleic, $4.6-6.9 \%$ palmitic and $0.25-4.6 \%$ stearic acids (21-23).

In this work, the $\omega-6 / \omega-3$ family polyunsaturated fatty acid ratio was around 0.24 . An $\omega-6$ to $\omega-3$ essential fatty acid ratio of approx. 1 is considered nutritionally adequate (24). A lower $\omega-6 / \omega-3$ fatty acid ratio is more desirable in reducing the risk of chronic diseases since polyunsaturated fatty acids are considered essential to the human body with nutritional advantages as long chain fatty acid (linoleic and linolenic acids) precursors. They can improve the brain, heart and immune system performance in humans, as well as have suppressive effects on the onset of cardiovascular, inflammatory and cancer diseases $(24,25)$.

The main advantage of extraction with subcritical propane are milder operating conditions than with supercritical $\mathrm{CO}_{2}$. The use of propane reduced drastically operation pressure, and enabled its industrial application based on a cost analysis for implementation feasibility.

\section{Physicochemical characterization}

Physicochemical analyses are crucial for oil quality evaluation. Table 4 shows brown linseed oil acidity, refraction indices and density values after different extraction methods. The samples with high yield (central point, assays 5, 6 and 7) were used for extractions with subcritical propane and pressurized ethanol.

As observable in Table 4, the density and refractive indices were not statistically significant $(p<0.05)$ for all linseed oil samples using the different extraction methods, as confirmed by Tukey's test, with $95 \%$ confidence level. According to the Adolfo Lutz Institute, Brazil (15), the refraction index is a good oil quality indicator and is affected by oxidation, heat treatment and free fatty acid content from oil. Gunstone et al. (26) and Firestone (27) recommend values from 0.924 to $0.930 \mathrm{~g} / \mathrm{cm}^{3}$.

Table 3. Fatty acid ester values from brown linseed oil extracted using subcritical propane, pressurized ethanol, organic solvent, and mechanical pressing (commercial sample)

\begin{tabular}{|c|c|c|c|c|c|}
\hline \multirow{2}{*}{\multicolumn{2}{|c|}{$\begin{array}{l}\text { Experimental } \\
\text { condition }\end{array}$}} & \multirow{3}{*}{ Yield/\% } & \multicolumn{3}{|c|}{ Fatty acid ester } \\
\hline & & & Linolenate $(\omega-3)$ & Linoleate $(\omega-6)$ & Oleate $(\omega-9)$ \\
\hline $\mathrm{p} / \mathrm{Pa}$ & $t /{ }^{\circ} \mathrm{C}$ & & \multicolumn{3}{|c|}{ Area/\% } \\
\hline \multicolumn{6}{|c|}{ Extraction with subcritical propane } \\
\hline $8 \cdot 10^{6}$ & 20 & $(26.9 \pm 1.0)^{\mathrm{a}}$ & $(53.7 \pm 0.4)^{\mathrm{b}}$ & $(13.1 \pm 0.7)^{\mathrm{a}}$ & $(19.2 \pm 0.6)^{b}$ \\
\hline $8 \cdot 10^{6}$ & 60 & $(27.6 \pm 1.0)^{\mathrm{a}}$ & $(54.8 \pm 0.7)^{\mathrm{a}}$ & $(12.3 \pm 0.1)^{\mathrm{a}}$ & $(19.7 \pm 0.1)^{b}$ \\
\hline $10^{7}$ & 40 & $(28.1 \pm 1.0)^{\mathrm{a}}$ & $(54.6 \pm 0.5)^{\mathrm{a}}$ & $(12.0 \pm 0.3)^{\mathrm{a}}$ & $(21.0 \pm 0.2)^{\mathrm{a}}$ \\
\hline $1.2 \cdot 10^{7}$ & 20 & $(27.1 \pm 1.0)^{\mathrm{a}}$ & $(52.9 \pm 0.2)^{c}$ & $(12.8 \pm 0.4)^{\mathrm{a}}$ & $(18.8 \pm 0.1)^{c}$ \\
\hline $1.2 \cdot 10^{7}$ & 60 & $(28.3 \pm 1.0)^{\mathrm{a}}$ & $(54.5 \pm 0.4)^{\mathrm{a}}$ & $(11.7 \pm 0.7)^{\mathrm{a}}$ & $(20.3 \pm 0.5)^{\mathrm{a}, \mathrm{b}}$ \\
\hline \multicolumn{6}{|c|}{ Extraction with pressurized ethanol } \\
\hline $8 \cdot 10^{6}$ & 20 & $(6.4 \pm 1.0)^{\mathrm{a}}$ & $(52.4 \pm 1.0)^{\mathrm{a}}$ & $(12.6 \pm 0.5)^{\mathrm{a}}$ & $(18.3 \pm 1.6)^{a}$ \\
\hline $8 \cdot 10^{6}$ & 60 & $(6.1 \pm 1.0)^{\mathrm{a}}$ & $(51.1 \pm 0.3)^{\mathrm{a}}$ & $(13.0 \pm 0.1)^{\mathrm{a}}$ & $(22.2 \pm 2.3)^{\mathrm{a}}$ \\
\hline $10^{7}$ & 40 & $(8.0 \pm 1.0)^{\mathrm{a}}$ & $(51.2 \pm 0.2)^{\mathrm{a}}$ & $(13.1 \pm 0.1)^{\mathrm{a}}$ & $(18.6 \pm 1.4)^{\mathrm{a}}$ \\
\hline $1.2 \cdot 10^{7}$ & 20 & $(7.0 \pm 1.0)^{\mathrm{a}}$ & $(53.4 \pm 2.0)^{\mathrm{a}}$ & $(13.6 \pm 0.6)^{\mathrm{a}}$ & $(18.7 \pm 1.2)^{\mathrm{a}}$ \\
\hline $1.2 \cdot 10^{7}$ & 60 & $(7.2 \pm 1.0)^{\mathrm{a}}$ & $(49.8 \pm 1.6)^{\mathrm{a}}$ & $(13.0 \pm 0.1)^{\mathrm{a}}$ & $(21.9 \pm 2.0)^{\mathrm{a}}$ \\
\hline \multicolumn{6}{|c|}{ Extraction with organic solvent } \\
\hline $10^{5}$ & 68 & 36.1 & $55.0 \pm 0.2$ & $12.4 \pm 0.2$ & $19.2 \pm 1.0$ \\
\hline \multicolumn{6}{|c|}{ Mechanical pressing } \\
\hline * & & 36.1 & $54.9 \pm 0.1$ & $12.5 \pm 0.5$ & $19.4 \pm 0.2$ \\
\hline
\end{tabular}

*Commercial sample. Same letters in columns in the same extraction method do not present any statistically significant difference according to the Tukey's test $(p<0.05)$ 
Table 4. Brown linseed oil physicochemical analysis results

\begin{tabular}{lccc}
\multirow{2}{*}{ Extraction } & \multicolumn{3}{c}{ Analysis } \\
\cline { 2 - 4 } Mechanical press & $(0.90 \pm 0.01)^{\mathrm{a}}$ & $(1.40 \pm 0.04)^{\mathrm{c}}$ & $(1.40 \pm 0.05)^{\mathrm{a}}$ \\
\cline { 2 - 4 } n-Hexane & $(0.90 \pm 0.01)^{\mathrm{a}}$ & $(1.50 \pm 0.01)^{\mathrm{b}}$ & $(1.40 \pm 0.04)^{\mathrm{a}}$ \\
Propane & $(0.90 \pm 0.01)^{\mathrm{a}}$ & $(0.90 \pm 0.01)^{\mathrm{d}}$ & $(1.40 \pm 0.01)^{\mathrm{a}}$ \\
Ethanol & $(0.90 \pm 0.01)^{\mathrm{a}}$ & $(1.70 \pm 0.02)^{\mathrm{a}}$ & $(1.40 \pm 0.01)^{\mathrm{a}}$ \\
\hline
\end{tabular}

*Same letters in columns do not represent any statistically significant difference according to the Tukey's test $(p<0.05)$

Linseed oil acidity was statistically different among all extraction methods studied. The highest (1.76 \%) and lowest $(0.95 \%)$ values were obtained using pressurized ethanol and subcritical propane, respectively. The highest acidity values were found after extractions with organic solvent (1.46\%) and pressurized ethanol (1.75\%). Such results were obtained since heating was used in both methods. Extractions using $n$ hexane $\left(68^{\circ} \mathrm{C}\right)$ and pressurized ethanol have a solvent evaporation step after the extraction. Heating can cause a triglyceride chain break during extraction, hence increasing acidity through fatty acid release (28). Thus, the physicochemical parameters indicate that oil extraction using subcritical propane was preferable due to fatty acid quality with low acidity.

\section{Cost analysis of the process}

The oil yield obtained with extraction using subcritical propane was around $28.3 \%$. Table 5 (29) shows fixed and variable costs, as well as oil total cost per litre. Fixed oil unit production cost was around US\$ 56540.00 and plant age was approx. 10 years. The total oil cost per litre is high when produced in a laboratory scale unit, as it yields small quantities of linseed oil ( $0.48 \mathrm{~L} /$ day).

Table 5. Production costs of $1 \mathrm{~L}$ linseed oil extracted with propane

\begin{tabular}{lcc} 
Item & Quantity & Amount (US\$) \\
Fixed cost & & \\
\hline Extractor unit & 1 & 6000.00 \\
Oven dryer & 1 & 200.00 \\
Mixer & 1 & 40.00 \\
Freezer & 1 & 300.00 \\
Building & & 50000.00 \\
Repair and maintenance (1 \%) & 5654.00 \\
Depreciation (10\%) & & 565.40 \\
Interest (2 \%) & & 113.08 \\
Total & & 62872.48 \\
Cost/L (0.48 L/day) & & 4.62 \\
\hline Variable cost & & $1.63^{*}$ \\
\hline Seed cost (monthly cost) & 50.00 \\
Electricity (monthly cost) & & 100.00 \\
Chemicals, reagents and gas & & \\
(monthly cost) & & 1000.00 \\
Labour (skilled and operator & & 1151.63 \\
helpers) (monthly cost) & & 124.58 \\
Total & & \\
Cost/L (0.48L/day) & & \\
\hline Total cost per litre & & \\
\hline
\end{tabular}

*Seed cost was based on Flax Council of Canada International Market (29)
Galvão et al. (30) reported a US\$ 13.21/kg specific cost when evaluating the supercritical technology $\left(\mathrm{CO}_{2}\right.$ solvent) costs for flaxseed oil extraction, whereas linseed oil obtained by cold mechanical pressing is marketed at US\$54.00/kg in Brazil (31). These costs when compared to those for propane extraction make it a non-market-competitive technology. However, industrial-scale propane extraction (increased capacity) could reduce subcritical extraction costs, making it an attractive method.

\section{CONCLUSIONS}

Physicochemical analyses of density and refractive index of oil samples obtained using the different extraction methods were similar. All extraction methods gave similar fatty acid ester profile. The subcritical propane was an efficient method for brown linseed oil extraction achieving good yield, maintaining the quality and quantity of fatty acids at mild temperature and pressure conditions, and completly removing the solvent from the final product. Since extraction using subcritical propane was economically feasible on a laboratory scale, an industrial scale process is recommended for capacity increase.

\section{ACKNOWLEDGEMENTS}

The authors greatly appreciate the help of their colleagues at the Department of Food Engineering, URI Erechim, RS, and CAPES, Erechim, Brazil.

\section{REFERENCES}

1. Khan LM, Sharif M, Sarwar M, Sameea, Ameen M. Chemical composition of different varieties of linseed. Pak Vet J.2010; 30(2):79-82.

2. Zanqui AB, de Morais DR, da Silva CM, Santos JM, Gomes STM, Visentainer JV, et al. Subcritical extraction of flaxseed oil with n-propane: Composition and purity. Food Chem. 2015;188:452-8.

https://doi.org/10.1016/j.foodchem.2015.05.033

3. Pradhan RC, Meda V, Rout PK, Naik S, Dalai AK. Supercritical $\mathrm{CO}_{2}$ extraction of fatty oil from flaxseed and comparison with screw press expression and solvent extraction processes. J Food Eng. 2010;98(4):393-7.

https://doi.org/10.1016/j.jfoodeng.2009.11.021

4. Mendiola JA, Herrero M, Cifuentes A, Ibañes E. Use of compressed fluids for sample preparation: Food applications. J Chromatogr A. 2007;1152(1-2):234-46.

https://doi.org/10.1016/j.chroma.2007.02.046

5. Jesus AA, Almeida LC, Silva LC, Filho LC, Egues SMS, Franceschi $E$, et al. Extraction of palm oil using propane, ethanol and its mixtures the compressed solvent. J Supercrit Fluids. 2013;81:245-53.

https://doi.org/10.1016/j.supflu.2013.06.011

6. Saha S, Walia S, Kundu A, Sharma K, Paul RK. Optimal extraction and fingerprinting of carotenoids by accelerated 
solvent extraction and liquid chromatography with tandem mass spectrometry. Food Chem. 2015;177:369-75.

https://doi.org/10.1016/j.foodchem.2015.01.039

7. Mustafa A, Turner C. Pressurized liquid extraction as a green approach in food and herbal plants extraction: A review. Anal Chim Acta. 2011;703(1):8-18.

https://doi.org/10.1016/j.aca.2011.07.018

8. Liu Z, Mei L, Wang Q, Shao Y, Tao Y. Optimization of subcritical fluid extraction of seed oil from Nitraria tangutorum using response surface methodology. LWT - Food Sci Technol. 2014;56(1):168-74.

https://doi.org/10.1016/j.lwt.2013.10.048

9. Bozan B, Temelli F. Supercritical $\mathrm{CO}_{2}$ extraction of flaxseed. J Am Oil Chem Soc. 2002;79(3):231-5. https://doi.org/10.1007/s11746-002-0466-x

10. Pessoa AS, Podestá R, Bloc JM, Franceschi E, Dariva C, Lanza M. Extraction of pequi (Caryocar coriaceum) pulp oil using subcritical propane: Determination of process yield and fatty acid profile. J Supercrit Fluid. 2015;101:95-103.

https://doi.org/10.1016/j.supflu.2015.03.006

11. Corso MP, Fagundes-Klen MR, Silva EA, Filho LC, Santos JN, Freitas LS, Dariva C. Extraction of sesame seed (Sesamun indicum L.) oil using compressed propane and supercritical carbon dioxide. J Supercrit Fluid. 2010;52(1):56-61. https://doi.org/10.1016/j.supflu.2009.11.012

12. Nimet $G$, da Silva EA, Palú F, Dariva C, dos Santos Freitas $L$, Neto AM, Filho LC. Extraction of sunflower (Heliantus annuus L.) oil with supercritical $\mathrm{CO}_{2}$ and subcritical propane: Experimental and modeling. Chem Eng J. 2011;168(1):262-8. https://doi.org/10.1016/j.cej.2010.12.088

13. Illés V, Daood HG, Perneczki S, Szokonya L, Then M. Extraction of coriander seed oil by $\mathrm{CO}_{2}$ and propane at super- and subcritical conditions. J Supercrit Fluid. 2000;17(2):177-86. https://doi.org/10.1016/S0896-8446(99)00049-2

14. Khattab RY, Zeitoun MA. Quality evaluation of flaxseed oil obtained by different extraction techniques. LWT - Food Sci Technol. 2013;53(1):338-45.

https://doi.org/10.1016/j.lwt.2013.01.004

15. Analytical standards of the Adolfo Lutz Institute. Physico-chemical analysis of foods. São Paulo, Brazil: Adolfo Lutz Institute; 2008.

16. CONTAGRI. Software in rural management, v. 1, EPAGRI SA, Florianópolis, Brazil; 2002. Available from: http://www.contagri.com.br/.

17. Statistica, v. 5.0, StatSoft, Inc, Tulsa OK, USA; 2012. Avaliable from: http://www.stasoft.com.

18. dos Santos Freitas L, de Oliveira JV, Dariva C, Jacques RA, Caramão EB. Extraction of grape seed oil using compressed carbon dioxide and propane: Extraction yields and characterization of free glycerol compounds. J Agric Food Chem. 2008;56(8):2558-64.

https://doi.org/10.1021/jf0732096
19. Pederssetti MM, Palú F, da Silva EA, Rohling JH, Cardozo-Filho L, Dariva C. Extraction of canola seed (Brassica napus) oil using compressed propane and supercritical carbon dioxide. J Food Eng. 2011;102(2):189-96.

https://doi.org/10.1016/j.jfoodeng.2010.08.018

20. Ivanov DS, Čolović RR, Lević JD, Sredanović SA. Optimization of supercritical fluid extraction of linseed oil using RSM. Eur J Lipid Sci Technol. 2012;114(7):807-15. https://doi.org/10.1002/ejlt.201100347

21. Bayrak A, Kiralan M, Ipek A, Arslan N, Cosge B, Khawar KM. Fatty acid compositions of linseed (Linum usitatissimum L.) genotypes of different origin cultivated in Turkey. Biotechnol Biotechnol Equip. 2010;24(2):1836-42.

https://doi.org/10.2478/V101330-010-0034-2

22. Krist S, Stuebiger G, Bail S, Unterweger H. Analysis of volatile compounds and triacylglycerol composition of fatty seed oil gained from flax and false flax. Eur J Lipid Sci Technol. 2006;108(1):48-60.

https://doi.org/10.1002/ejlt.200500267

23. Van Ruth SM, Shaker EM, Morrissey PA. Influence of methanolic extracts of soybean seeds and soybean oil on lipid oxidation in linseed oil. Food Chem. 2001;75(2):177-84. https://doi.org/10.1016/S0308-8146(01)001950-9

24. Simopoulos AP. The importance of the omega-6/omega-3 fatty acid ratio in cardiovascular disease and other chronic diseases. Exp Biol Med. 2008;233(6):674-88.

https://doi.org/10.31818/0711-MR-311

25. Simopoulos AP. Evolutionary aspects of diet, the omega-6/ omega-3 ratio and genetic variation: Nutritional implications for chronic diseases. Biomed Pharmacother. 2006; 60(9):502-7.

https://doi.org/10.1016/j.biopha.2006.07.080

26. Gunstone FD, Harwood JL, Dijkstra AJ. The lipid handbook. Boca Raton, FL, USA: Taylor \& Francis Group; 2007.

27. Firestone D. Physical and chemical characteristics of oils, fats, and waxes. Urbana, IL, USA: AOCS Press; 2006.

28. Tonon RV, Grosso CRF, Hubinger MD. Influence of emulsion composition and inlet air temperature on the microencapsulation of flaxseed oil by spray drying. Food Res Int. 2011; 44(1):282-9.

https://doi.org/10.1016/j.foodres.2010.10.018

29. Flax Council of Canada. Winnipeg, Canada. Available from: https://flaxcouncil.ca/.

30. Galvão EL, Martínez J, de Oliveira HNM, de Sousa EMBD. Supercritical extraction of linseed oil: Economical viability and modeling extraction curves. Chem Eng Commun. 2013;200(2):205-21.

https://doi.org/10.1080/00986445.2012.699482

31. Naturalis. Online Store; 2012. Available from: https://loja. naturalis.com.br. 